\title{
Copper-Free Sonogashira Coupling of Aryl Chlorides with $\mathrm{Pd} / \mathrm{C}$
}

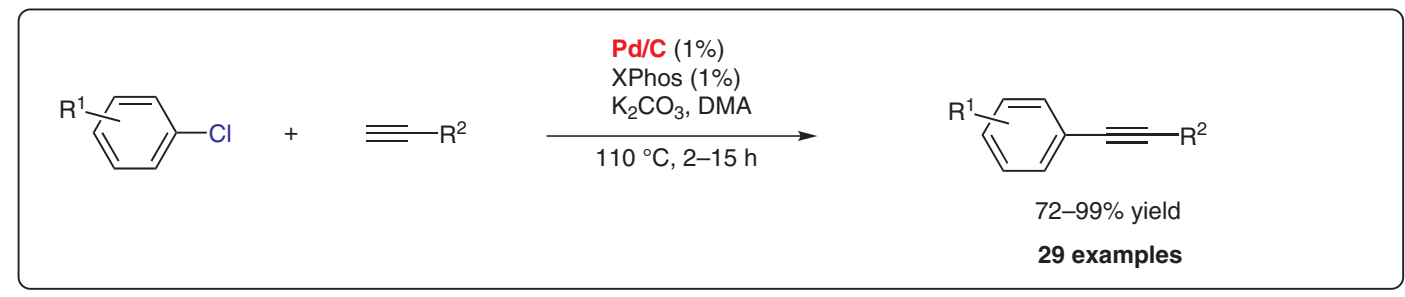

palladium on

charcoal

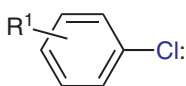<smiles>Clc1ccccc1</smiles><smiles>Fc1ccc(Cl)cc1</smiles><smiles>O=[N+]([O-])c1ccc(Cl)cc1</smiles><smiles>Cc1ccc(Cl)cc1</smiles><smiles>Cc1ccccc1Cl</smiles><smiles>N#Cc1ccc(Cl)cc1</smiles><smiles>COc1ccc(Cl)cc1</smiles><smiles>N#CCc1ccc(Cl)cc1</smiles><smiles>CC(=O)c1ccc(Cl)cc1</smiles><smiles>Cc1cccc(C)c1Cl</smiles><smiles>FC(F)(F)c1ccc(Cl)cc1</smiles><smiles>CC(=O)Nc1ccc(Cl)cc1</smiles><smiles>Clc1cccs1</smiles><smiles>Clc1ccccn1</smiles><smiles>[R]C#C</smiles><smiles>C#Cc1ccccc1</smiles><smiles>C#Cc1cccc(C)c1</smiles><smiles>C#Cc1ccc2ccccc2c1</smiles><smiles>C#CCCCCC</smiles><smiles>C#C[In]</smiles><smiles>C#CC1(O)CCCCC1</smiles><smiles>CCCc1cc(P)c(-c2ccccc2P)c(C(C)C)c1</smiles>

Significance: The Sonogashira coupling of aryl chlorides with terminal acetylenes under copperfree conditions in the presence of a palladium on charcoal catalyst were described. To a suspension of 10\% Pd/C Selcat Q6 (5 mg, $0.005 \mathrm{mmol})$, XPhos (2.4 mg, $0.005 \mathrm{mmol}$ ) and $\mathrm{K}_{2} \mathrm{CO}_{3}(97 \mathrm{mg}$, $0.75 \mathrm{mmol})$ in dimethylacetaminde $(0.25 \mathrm{~mL})$ under argon were added an aryl chloride $(0.5 \mathrm{mmol})$ and an alkyne $(0.75 \mathrm{mmol})$. The reaction mixture was stirred at $110^{\circ} \mathrm{C}$ to give the Sonogashira coupling product (29 examples: $72-99 \%$ yield).
Comment: The authors also showed recycling of the $\mathrm{Pd} / \mathrm{C}$ catalyst (five times). The activity of the recycled catalyst decreased after each run. Prolonged reaction time realized full conversion in every repeated run $(12,16,18,20$ and 24 h, respectively). The authors tested several commercially available Pd/C catalysts (Selcat Q6, Selcat H6, Selcat A6, Degussa E196 KP/D, Degussa E1702 KP/D, Degussa E196 WN/D, Hereaus K0218, Dutral, Panreac, Fluka, and Norit A). The type of the applied catalyst is essential for successful coupling. 